\title{
Managers' Spirituality at Work and Transformational Leadership Style in Tehran University of Medical Sciences, 2012
}

\author{
Azimeh Ghorbanian ${ }^{1}$; Mohsen Ghorbanian ${ }^{1}$; Sodabeh Vatankhah ${ }^{2}$; Mohammadkarim \\ Bahadori $^{3, ;} ;$ Ramin Ravangard $^{4}$ \\ ${ }^{1}$ Student Research Committee, Shiraz University of Medical Sciences, Shiraz, IR Iran \\ 2 Department of Health Services Management, Iran University of Medical Sciences, Tehran, IR Iran \\ ${ }^{3}$ Health Management Research Center, Baqiyatallah University of Medical Sciences, Tehran, IR Iran \\ ${ }^{4}$ Department of Health Services Management, School of Management and Medical Information Sciences, Shiraz University of Medical Sciences, Shiraz, IR Iran \\ *Corresponding author: Mohammadkarim Bahadori, Health Management Research Center, Baqiyatallah University of Medical Sciences, Tehran, IR Iran. Tel: +98-2182482417, Fax: +98- \\ 2188057022, E-mail: bahadorihealth@gmail.com
}

Received: June 16, 2014; Revised: July 23, 2014; Accepted: September 10, 2014

Background:In today's changing and uncertain environment, there is a need for transformational leaders. Besides, due to lack of effective leaders in organizations, identifying factors influencing managers to act as transformational managers is very important. Spirituality is one of the factors, which cause managers to act as transformational managers.

Objectives: This study aimed to investigate the association between managers' spirituality at work and their leadership styles in Tehran University of Medical Sciences, Tehran, Iran in 2012.

Materials and Methods: This was an applied, cross-sectional and descriptive-analytic study conducted on all managers at different levels $(n=44)$ and a sample of 74 employees of the Vice Chancellor of Management Development and Resource Planning of Tehran University of Medical Sciences, Tehran, Iran in 2012. Data was collected using two questionnaires evaluating managers' leadership styles and their spirituality at work. Collected data was analyzed using SPSS 16.0 by Pearson Correlation Coefficient and Multiple Linear Regression (Stepwise method). $\mathrm{P}<0.05$ was considered statistically significant.

Results: There were positive and significant correlations between transformational leadership style and managers' spirituality at work $(\mathrm{r}=0.364, \mathrm{P}<0.001)$ and between transformational leadership style and all dimensions of managers' spirituality at work $(\mathrm{P}<0.05)$. Multiple Linear Regression showed that among the dimensions of managers' spirituality at work, only interpersonal communication had a significant effect on using transformational leadership style by managers $(\mathrm{P}=0.001)$.

Conclusions: If managers' spirituality at work, especially interpersonal communication skills improves, their use of transformational leadership would be increased. Therefore, it seems necessary to employ individuals with great interpersonal communication skills and good communication with other people and colleagues, teams, formal and informal organizations as managers. Furthermore, it is recommended to continuously improve managers' communication skills to enable them to act as transformational managers.

Keywords:Transformational Leadership; Transactional Leadership; Laissez-Faire Leadership

\section{Background}

The most striking characteristic of the current era is large and continuous changes occurring in different areas $(1,2)$. To deal with uncertain environment and continuous changes, transformational leaders and managers would be required because transformational leadership and management enable the organization to improve its performance in a competitive, uncertain and unpredictable environment $(3,4)$. Leadership style is a manager or leader's continuous behavioral pattern perceived by others, and he or she uses it when working with others or doing work by others (5). Leadership styles based on a new classification are categorized into transformational, transactional and laissez-faire ones. Among these three styles of leadership, transformational leadership style has been more considered because of its desirable characteristics $(6,7)$. Transformational leadership style focuses on developing and empowering followers to function independently, and is a process by which leaders and followers promote each other to higher levels of morality and motivation. Transformational leaders and managers have great insights and try to make others to do extraordinary work and activities $(8,9)$. On the other hand, transactional leaders motivate their followers towards predetermined goals and objectives $(10,11)$. However, laissez-faire leadership is to free followers from being led or to avoid leading, which is the most passive style in the spectrum of leadership styles. In this style, the leader or manager avoids making decisions and shifts his or her responsibilities to others. Therefore, employees' motivation is reduced to a minimum and leader's foresight and insight is eliminated $(12,13)$. The present study was conducted based on the Bernard M. Bass's studies on transformational leadership.

Copyright ( 2014, Kowsar Corp. This is an open-access article distributed under the terms of the Creative Commons Attribution-NonCommercial 4.0 International License (http://creativecommons.org/licenses/by-nc/4.0/) which permits copy and redistribute the material just in noncommercial usages, provided the original work is properly cited. 
According to his definition, four important dimensions of transformational leadership include: idealized influence (leader or manager's attributes and behavior), inspirational motivation, intellectual stimulation and individualized consideration $(14,15)$. In the recent years, many studies have been conducted on transformational leadership and its advantages. According to the results of these studies, transformational leadership increases organizational productivity, organizational performance, organizational learning and organizational commitment, employees' job satisfaction and self-actualization, collective efficacy and actualization, performance of work groups, and producing intermediate outcomes such as shared vision (16-22). Moreover, transformational leadership can decrease employees' job stress, turnover intentions, burnout, and intention to leave the organization (23-25). Therefore, identifying factors influencing managers to act as transformational managers is very important. In addition to the research performed on the advantages of using transformational leadership style in organizations, some studies were conducted on managers and leaders' characteristics, which make them act as transformational managers. According to their results, spirituality is one of the factors, which cause managers to act as transformational managers $(26,27)$. Spirituality has recently entered the fields of Management and Organization $(28,29)$ and over the last decade, spirituality concept has been adequately considered at work (30-34). Spirituality refers to trying to establish person's sensitivity to himself or herself, others and God, search for what is needed for becoming a human, and search for the perfect man $(35,36)$. In general, spirituality at work has been defined as trying to develop sensitivity to four kinds of communication, containing super-personal communication, interpersonal communication, intrapersonal communication and exterpersonal communication. Super-personal communication refers to person's relationships with transphysical phenomena including God, etc. Intrapersonal communication refers to person's relationships with himself or herself. Interpersonal communication indicates person's relationships with other people, and exterpersonal communication denotes person's relationships with natural and non-human environment. In this definition, being a spiritual person is determined through investigating how to establish these four relationships. In fact, being spiritual has a cross-religious concept and does not belong to any certain and particular religion $(37,38)$. Spirituality in organizations has some benefits for employees and supports organizational performance. Based on the results of some studies, spirituality increases employees' well-being and quality of life, gives personnel a sense of purpose and meaning at work, and gives them a sense of mutual understanding and interrelatedness. To promote one's personality, spirituality at work is the bridge between human's biological, psychological, social and spiritual dimensions and self-actualization, meaningful and purposeful work. Important achievements of spirituality at work are peace, happiness and hope which are the main components of inward satisfaction including satisfaction both in personal life and work life $(39,40)$.

\section{Objectives}

This study aimed to investigate the association between dimensions of managers' spirituality at work and their leadership styles.

\section{Materials and Methods}

This was an applied, cross-sectional and descriptive-analytic study conducted on managers (at different levels including top, middle and operational managers) and employees of the Vice Chancellor of Management Development and Resource Planning of Tehran University of Medical Sciences, Tehran, Iran in 2012. All managers ( $\mathrm{n}=$ 44) and a sample of 74 employees, selected using simple random sampling method, were studied. The sample size of employees was determined using the findings of previous studies assuming $\alpha=0.05, \mathrm{~d}=4.7$ and $\sigma=20.6$. Required data on the leadership styles was collected using the Multifactor Leadership Questionnaire (MLQ), which its inter-item consistency score was found to be adequate $(\alpha=0.91)$. This questionnaire has two separate forms evaluating managers' leadership style from the viewpoints of both managers themselves and their followers and employees. Therefore, the manager-related forms indicating managers' views about their leadership styles were completed by the studied managers. Besides, the studied employees completed the follower-related forms indicating followers and employees' perspectives on their managers' leadership styles. Another questionnaire developed by Abedijafari and Rastegar (41) was used to evaluate the level of managers' spirituality at work, including Spiritual Well Being Scale (SWBS), Spiritual Transcendence Scale (STS), and Spirituality Assessment Scale (SAS). This questionnaire examined four kinds of employees' communication, including super-personal communication, interpersonal communication, intrapersonal communication, and exterpersonal communication. Its reliability had been confirmed in their study previously $(\alpha=0.92)$. Five-point Likert scales were used to measure managers' leadership styles and their spirituality at work, whereby one referred to strongly disagree and five as strongly agree. Informed consent was obtained from all managers and employees participating in this study. All participants were assured of the confidentiality of their responses. Collected data was analyzed using SPSS 16.0 by Pearson Correlation Coefficient and Multiple Linear Regression (Stepwise method). $\mathrm{P}<0.05$ was considered statistically significant.

\section{Results}

A half of the studied managers were male (50\%). Most of 44 studied managers were in the 40-50 years age group (43.2\%), married (81.8\%), employed officially (90.9\%), in the 
10-20 years job experience group (47.7\%), and had a bachelor's degree (56.8\%). On the other hand, most of 74 studied employees were female (58.1\%), married (58.1\%), employed officially (56.8\%), and younger than 30 years (67.6\%), less than five years job experience (70.3\%), and a bachelor's degree (51.4\%) (Table 1). Transformational leadership and laissez-faire leadership styles had the highest and lowest means, respectively, both from studied managers (4.09 \pm 0.38 vs. $2.60 \pm 0.81$ ) and employees' viewpoints (3.68 \pm 0.74 $v$ s. 2.47 \pm 0.98 ) indicating that managers believed that they acted more as transformational managers, also the employees believed that their managers mostly directed and managed them transformationally. Furthermore, among the dimensions of managers' spirituality at work, superpersonal communication and exterpersonal communication had the highest and lowest means, respectively, from the viewpoints of both managers (3.98 $\pm 0.43 \mathrm{vs} .3 .79$ $\pm 0.42)$ and employees ( $4.03 \pm 0.39$ vs. $3.69 \pm 0.37)$ (Table 2). On the other hand, unlike laissez-faire leadership style, transformational $(\mathrm{r}=0.364, \mathrm{P}<0.001)$ and transactional $(\mathrm{r}=0.229, \mathrm{P}=0.013)$ leadership styles had positive and significant correlations with managers' spirituality at work (Table 3). In addition, transformational leadership style had positive and significant correlations with all dimensions of managers' spirituality at work $(\mathrm{P}<0.05)$ (Table 4 ) indicating that increase in each kind of communication would increase using transformational leadership style by managers. Furthermore, managers' spirituality at work had positive and significant correlations with all dimensions of transformational leadership style $(\mathrm{P}<0.05)$ (Table 5) indicating that increase in each dimension of transformational leadership style would increase managers' spirituality at work. Finally, Multiple Linear Regression showed that among the dimensions of managers' spirituality at work, only interpersonal communication had significant association with using transformational leadership style by managers $(P=0.001$ ) (Table 6$)$, so that $16.5 \%$ of the variance in using transformational leadership style could be explained by interpersonal communication $\left(\mathrm{R}^{2}\right.$ adjusted $\left.=0.165\right)$.

\begin{tabular}{|c|c|c|c|}
\hline & Managers & Employees & Total \\
\hline \multicolumn{4}{|l|}{ Gender } \\
\hline Male & $22(50)$ & $31(41.9)$ & $53(44.9)$ \\
\hline Female & $22(50)$ & $43(58.1)$ & $65(55.1)$ \\
\hline Total & $44(100)$ & $74(100)$ & $118(100)$ \\
\hline \multicolumn{4}{|l|}{ Age } \\
\hline Younger than 30 years & $6(13.6)$ & $50(67.6)$ & $56(47.5)$ \\
\hline 30-40 Years & $13(29.5)$ & $17(23)$ & $30(25.4)$ \\
\hline 40-50 Years & $19(43.2)$ & $6(8.1)$ & $25(21.2)$ \\
\hline 50-60 Years & $6(13.6)$ & $1(1.4)$ & $7(5.9)$ \\
\hline Total & $44(100)$ & $74(100)$ & $118(100)$ \\
\hline \multicolumn{4}{|l|}{ Marital Status } \\
\hline Single & $8(18.2)$ & $31(41.9)$ & $39(33.1)$ \\
\hline Married & $36(81.8)$ & $43(58.1)$ & $79(66.9)$ \\
\hline Total & $44(100)$ & $74(100)$ & $118(100)$ \\
\hline \multicolumn{4}{|l|}{ Education Level } \\
\hline Diploma & $3(6.8)$ & $10(13.5)$ & $13(11)$ \\
\hline Associate degree & $0(0)$ & $9(12.2)$ & $9(7.6)$ \\
\hline Bachelor's degreed & $25(56.8)$ & $38(51.4)$ & $63(53.4)$ \\
\hline Master's degrees & $15(34.1)$ & $16(21.6)$ & $31(26.3)$ \\
\hline Philosophy of doctor & $1(2.3)$ & $1(1.4)$ & $2(1.7)$ \\
\hline Total & $44(100)$ & $74(100)$ & $118(100)$ \\
\hline \multicolumn{4}{|l|}{ Employment Status } \\
\hline Official & $40(90.9)$ & $42(56.8)$ & $82(69.5)$ \\
\hline Contractual & $4(9.1)$ & $32(43.2)$ & $36(30.5)$ \\
\hline Total & $44(100)$ & $74(100)$ & $118(100)$ \\
\hline \multicolumn{4}{|l|}{ Job Experience } \\
\hline Less than 5 Years & $3(6.8)$ & $52(70.3)$ & $55(46.6)$ \\
\hline 5-10 Years & $4(9.1)$ & $10(13.5)$ & $14(11.9)$ \\
\hline 10-20 Years & $21(47.7)$ & $9(12.2)$ & $30(25.4)$ \\
\hline 20-30 Years & $16(36.4)$ & $3(4.1)$ & $19(16.1)$ \\
\hline Total & $44(100)$ & $74(100)$ & $118(100)$ \\
\hline
\end{tabular}

\footnotetext{
${ }^{\mathrm{a}}$ Data are presented as No.(\%).
} 
Ghorbanian A et al.

\begin{tabular}{lccc}
\hline \multicolumn{2}{l}{ Table 2. Managers' Leadership Styles and Their Spirituality at Work From the Viewpoints of Studied Managers and Employees ${ }^{\text {a }}$} \\
\hline Studied Samples Variables & Managers, No. & Employees, No. & Total, No. \\
\hline Leadership Styles & & & $3.83 \pm 0.66$ \\
Transformational leadership & $4.09 \pm 0.38$ & $3.68 \pm 0.74$ & $3.54 \pm 0.52$ \\
Transactional leadership & $3.74 \pm 0.46$ & $3.42 \pm 0.52$ & $2.52 \pm 0.92$ \\
\hline Laissez-faire leadership & $2.60 \pm 0.81$ & $2.47 \pm 0.98$ & $4.03 \pm 0.39$ \\
Dimensions of Managers' Spirituality at Work & & & $3.78 \pm 0.31$ \\
\hline Super-personal communication & $3.98 \pm 0.43$ & $4.06 \pm 0.36$ & $3.89 \pm 0.41$ \\
\hline Intrapersonal communication & $3.81 \pm 0.35$ & $3.76 \pm 0.29$ & $3.69 \pm 0.37$ \\
\hline Interpersonal communication & $3.94 \pm 0.42$ & $3.85 \pm 0.41$ & $3.85 \pm 0.26$ \\
\hline Exterpersonal communication & $3.79 \pm 0.42$ & $3.63 \pm 0.33$ & $3.82 \pm 0.25$ \\
\hline Total (managers' spirituality at work) & $3.88 \pm 0.29$ & & \\
\hline
\end{tabular}

${ }^{\mathrm{a}}$ Data are presented as mean $\pm \mathrm{SD}$.

Table 3. The Correlations Between Managers' Leadership Styles and Their Spirituality at Work

\begin{tabular}{lccc}
\hline & Transformational Leadership & Transactional Leadership & Laissez-Faire Leadership \\
\hline $\mathbf{r}$ & 0.364 & 0.229 & 0.063 \\
$\mathbf{P}$ value & $<0.001$ & 0.013 & $<0.499$ \\
\hline
\end{tabular}

Table 4. The Correlations Between Transformational Leadership Style and the Dimensions of Managers' Spirituality at Work

\begin{tabular}{lcccc}
\hline & $\begin{array}{c}\text { Super-personal } \\
\text { Communication }\end{array}$ & $\begin{array}{c}\text { Intrapersonal } \\
\text { Communication }\end{array}$ & $\begin{array}{c}\text { Interpersonal } \\
\text { Communication }\end{array}$ & $\begin{array}{c}\text { Exterpersonal } \\
\text { Communication }\end{array}$ \\
\hline $\mathbf{r}$ & 0.204 & 0.184 & 0.240 & 0.386 \\
Pvalue & 0.025 & 0.046 & 0.009 & $<0.001$ \\
\hline
\end{tabular}

Table 5. The Correlations Between Managers' Spirituality at Work and the Dimensions of Transformational Leadership

\begin{tabular}{lccccc}
\hline & $\begin{array}{c}\text { Idealized Influence } \\
\text { (Behaviors) }\end{array}$ & $\begin{array}{c}\text { Idealized Influence } \\
\text { (Attributes) }\end{array}$ & $\begin{array}{c}\text { Inspirational } \\
\text { Motivation }\end{array}$ & $\begin{array}{c}\text { Intellectual } \\
\text { Stimulation }\end{array}$ & $\begin{array}{c}\text { Individualized } \\
\text { Consideration }\end{array}$ \\
\hline $\mathbf{r}$ & 0.184 & 0.249 & 0.217 & 0.200 & 0.192 \\
PValue & 0.046 & 0.007 & 0.018 & 0.030 & 0.038 \\
\hline
\end{tabular}

Table 6. The Effects of the Dimensions of Managers' Spirituality at Work on Using Transformational Leadership by Managers Using Multiple Linear Regressions (Stepwise Method)

\begin{tabular}{lcccc}
\hline Dimensions of Managers' Spirituality at Work & B & SE & Beta & Pvalue \\
\hline Constant & 1.471 & 0.252 & - & 0.001 \\
Interpersonal communication & 0.384 & 0.126 & 0.430 & 0.001 \\
\hline
\end{tabular}

\section{Discussion}

Based on the present study results, studied managers believed that their leadership style was more transformational leadership and less laissez-faire leadership. The studied employees also had the same opinion about the leadership style of their managers. Transformational leadership has positive impact on employees and followers' performance (42). Likewise, super-personal communication and exterpersonal communication had the highest and lowest means, respectively, from the viewpoints of both managers and employees. On the other hand, there were positive and significant correlations between the dimensions of managers' spirituality at work and transformational leadership style, but only interpersonal communication had an effect on using transformational leadership style by managers indicating that using transformational leadership style by managers would be increased along with an increase in their interpersonal communication. It can be due to this issue 
that interpersonal communication is associated with social and psychological needs and some components such as respecting, teamwork and active listening, can result in maintaining and improving individuals' status and positions among others. Moreover, it can create a sense of responsibility and strengthen empathy, cooperation, coordination and consultation with others. Generally, interpersonal communication is the process of understanding, realizing and sharing meaning between an individual and other persons and, in most cases, it is established in formal situations and includes face-to-face communication provided verbally and non-verbally (41, 43). Interpersonal communication is developed for performing five functions, including: 1) Affinity function in which the individual seeks to join with others; 2) Information and understanding function in which the individual seeks to share information with and increase understanding of others; 3) Influence function which refers to impacting or influencing on others, the most common impact is impact on individuals' attitudes, beliefs, values and behavior; 4) Decision function, making a particular decision may be subject to communicating with others, and 5) Confirmation function in which the individual seeks to receive recognition, acknowledgement and confirmation from others. Each person in his or her interpersonal communication needs to communicate effectively and efficiently to perform the mentioned functions $(31,41,44)$. There are several studies on the association between spirituality and leadership style; some of which have focused on transformational leadership style $(26,27,45)$. These studies have used different scales and questionnaires for assessing spirituality. Riaz in a study to investigate the association between school principals' spirituality and their transformational leadership behavior used SWBS for measuring spirituality and MLQ Form$5 \mathrm{X}$ Short to measure transformational leadership style. The results of his study showed that only two subscales of transformational leadership style, including idealized influence (behaviors) and inspirational motivation, had significant associations with spirituality (46). However, in the present study, all dimensions of transformational leadership style had positive and significant correlations with the managers' spirituality at work. While a self-reported questionnaire was used in the Rias' study to measure spirituality at work, we measured the levels of spirituality by studying four kinds of communication. This can be a reason for the differences between these two study results. In the Franklin's study to investigate the effects of spirituality on servant leadership among small business entrepreneurs, SAS and Servant Leadership Profile (Revised) were used to assess the levels of spirituality and servant leadership, respectively. This study showed a negative and significant association between spirituality and servant leadership (47), which does not confirm the present study results. The differences between these two study results can be due to different leadership styles in these two studies. However, the results of Field's study
(48) showed a positive and significant correlation between managers' spirituality and their transformational leadership, so that managers with high spirituality acted more as transformational managers. Therefore, the results of Field's study are in line with the present study. Hartsfield is one of the researchers who studied the internal forces that cause managers to act as transformational managers. He used SWBS and MLQ to measure spirituality and leadership styles, respectively. The results of his study showed that spirituality had effects on managers to act as transformational managers. In addition, spirituality had influenced emotional intelligence and then both of them affected managers' self-efficacy. Consequently, caused managers to act more in a transformational manner (49). Spirituality directly and indirectly had caused managers to be transformational managers. Therefore, the results of Hartsfield's study are similar to the present study. Zwart studied the association between spirituality and transformational leadership in public, private, and nonprofit sector organizations using MLQ and SAS to assess leadership styles and spirituality, respectively. They found no significant associations between the dimensions of transformational leadership and spirituality dimensions unlike previous studies and the present one. He indicated some reasons for not finding any significant association, including differences in the tools and questionnaires used, differences in the dimensions of spirituality studied or not clearly determined participants and study population in the previous studies (50). However, as can be seen in other studies mentioned above, none of them studied the effects of spirituality at work dimensions on transformational leadership style. According to the present study, there was a significant correlation between managers' spirituality at work and their transformational leadership, and interpersonal communication had a significant effect on using this kind of leadership style. Therefore, considering the advantages of using transformational leadership, it seems necessary to increase managers' spirituality at work through training, selecting qualified managers, and some other ways. Consequently, they can more use transformational leadership style. Moreover, given the positive and significant association between interpersonal communication and using transformational leadership, it is essential to consider this kind of spirituality communication. If managers' interpersonal communication skills improve through performing abovementioned five functions, their use of transformational leadership would be increased. Therefore, it seems necessary to employ persons with great interpersonal communication skills and good communication with other people and colleagues, teams, formal and informal organizations as managers. Furthermore, it is recommended to continuously improve managers' communication skills to enable them to act as transformational managers and leaders. Therefore, it is better to strengthen managers' communication skills including intrapersonal communication (relation- 
ship with themselves), interpersonal communication (relationship with others), exterpersonal communication (relationship with nature), and interpersonal communication through providing ethical and managerial training. Moreover, it is suggested further studies on the association between managers' leadership styles and their spiritual intelligence.

\section{Acknowledgements}

We would like to thank all managers and employees of the Vice Chancellor of Management Development and Resource Planning of Tehran University of Medical Sciences who participated in this study for their kind cooperation with the researchers in collecting and analyzing required data.

\section{Authors' Contributions}

Azimeh Ghorbanian, SodabehVatankhah and Mohsen Ghorbanian conducted the study, concept and design and developed the methods. Azimeh Ghorbanian collected data. Mohammadkarim Bahadori and Ramin Ravangard analyzed and interpreted the data and wrote the primary draft of the manuscript. All the authors contributed to the revision of the manuscript, read, and approved the final version.

\section{Funding/Support}

This study was a research project supported financially by Tehran University of Medical Sciences, according to contract number 955 .

\section{References}

1. Erskine J, Hunter DJ, Small A, Hicks C, McGovern T, Lugsden E, et al. Leadership and transformational change in healthcare organisations: A qualitative analysis of the North East Transformation System. Health Services Manage Res. 2013;26(1):29-37.

2. Sullivan RL, Rothwell WJ, Balasi MJB. Organization development (OD) and change management (CM): whole system transformation. Dev Learning Organiz. 2013;27(6):18-23.

3. Lacasse C. Developing nursing leaders for the future: achieving competency for transformational leadership. Oncol Nurs Forum. 2013;40(5):431-3.

4. Ayoko OB, Konrad AM. Leaders' transformational, conflict, and emotion management behaviors in culturally diverse workgroups. Equality, Diversity Inclusion: An Int J. 2012;31(8):694-724.

5. arthasarathy., Govender J, Lall GH, Loganathan R. Leadership style and job satisfaction: A developing economy perspective. Corporate Ownership Control. 2013;10(4):390-9.

6. Eagly AH, Johannesen-Schmidt MC, van Engen ML. Transformational, transactional, and laissez-faire leadership styles: a meta-analysis comparing women and men. Psychol Bull. 2003;129(4):569-91.

7. Moors G. The effect of response style bias on the measurement of transformational, transactional, and laissez-faire leadership. Eur J Work Organiz Psychol. 2012;21(2):271-98.

8. Ewen C, Wihler A, Blickle G, Oerder K, Ellen BP, Douglas C, et al Further specification of the leader political skill-leadership effectiveness relationships: Transformational and transactional leader behavior as mediators. Leadership Quarterly. 2013;24(4):516-33.

9. Miao Q, Newman A, Lamb P. Transformational leadership and the work outcomes of Chinese migrant workers: The mediating effects of identification with leader. Leadership. 2012;8(4):377-95.
10. Moghimi M. organization and management By Reaserch. . Tehran: Termeh; 2006 .

11. Hartog DN, Muijen JJ, Koopman PL. Transactional versus transformational leadership: An analysis of the MLQ. J Occup Organiz Psychol.1997;70(1):19-34.

12. Xirasagar S. Transformational, transactional among physician and laissez-faire leadership among physician executives.J Health Organ Manag. 2008;22(6):599-613.

13. Furtner MR, Baldegger U, Rauthmann JF. Leading yourself and leading others: Linking self-leadership to transformational, transactional, and laissez-faire leadership. Eur J Work Organiz Psychol. 2013;22(4):436-49.

14. Bass BM. Two Decades of Research and Development in Transformational Leadership. EurJ Work Organiz Psychol. 1999;8(1):9-32.

15. Zhang W, Wang H, Pearce CL. Consideration for future consequences as an antecedent of transformational leadership behavior: The moderating effects of perceived dynamic work environment. Leadership Quarterly. 2014;25(2):329-43.

16. Menges JI, Walter F, Vogel B, Bruch H. Transformational leadership climate: Performance linkages, mechanisms, and boundary conditions at the organizational level. Leadership Quarterly. 2011;22(5):893-909.

17. Thompson J. Transformational leadership can improve workforce competencies. Nurs Manag (Harrow). 2012;18(10):21-4.

18. Nielsen K, Yarker J, Randall R, Munir F. The mediating effects of team and self-efficacy on the relationship between transformational leadership, and job satisfaction and psychological well-being in healthcare professionals: a cross-sectional questionnaire survey. Int J Nurs Stud. 2009;46(9):1236-44.

19. Wang X, Chontawan R, Nantsupawat R. Transformational leadership: effect on the job satisfaction of Registered Nurses in a hospital in China. J Adv Nurs. 2012;68(2):444-51.

20. Top M, Tarcan M, Tekingunduz S, Hikmet N. An analysis of relationships among transformational leadership, job satisfaction, organizational commitment and organizational trust in two Turkish hospitals. Int J Health Plann Manage. 2013;28(3):e217-41.

21. Franke F, Felfe J. How does transformational leadership impact employees' psychological strain?: Examining differentiated effects and the moderating role of affective organizational commitment. Leadership. 2011;7(3):295-316.

22. Wang P, Walumbwa FO. Family-Friendly Programs, Organizational Commitment, and Work Withdrawal: The Moderating Role of Transformational Leadership. Personnel Psychol. 2007; 60(2):397-427.

23. Syrek CJ, Apostel E, Antoni CH. Stress in highly demanding IT jobs: transformational leadership moderates the impact of time pressure on exhaustion and work-life balance. J Occup Health Psychol. 2013;18(3):252-61.

24. Green AE, Miller EA, Aarons GA. Transformational leadership moderates the relationship between emotional exhaustion and turnover intention among community mental health providers. Community Ment Health J. 2013;49(4):373-9.

25. Tse HHM, Huang X, Lam W. Why does transformational leadership matter for employee turnover? A multi-foci social exchange perspective. Leadership Quart. 2013;24(5):763-76.

26. Krishnan VR. The Impact of Transformational Leadership on Followers' Duty Orientation and Spirituality. J Human Values. 2008;14(1):11-22.

27. McKee MC, Driscoll C, Kelloway EK, Kelley E. Exploring linkages among transformational leadership, workplace spirituality and well-being in health care workers. J Manage Spiritual Relig. 2011;8(3):233-55.

28. Daly CC. Definition of terms: spirituality versus religiousness South Med J. 2005;98(12):1238-9.

29. Gall TL, Malette J, Guirguis YM. Spirituality and Religiousness: A Diversity of Definitions.J Spirituality Ment Health. 2011;13(3):158-81.

30. Dent EB, Higgins ME, Wharff DM. Spirituality and leadership: An empirical review of definitions, distinctions, and embedded assumptions. Leadership Quart. 2005;16(5):625-53.

31. Milliman J, Czaplewski AJ, Ferguson J. Workplace spirituality and employee work attitudes: An exploratory empirical assessment. JOrganiz Change Manage. 2003;16(4):426-47. 
32. Garcia Z, Jean C. Workplace Spirituality and Organizational Performance. Public Administr Review. 2003;63(3):355-63.

33. Naimon EC, Mullins ME, Osatuke K. The effects of personality and spirituality on workplace incivility perceptions. J Manage Spirituality Relig. 2013;10(1):91-110.

34. Gupta M, Kumar V, Singh M. Creating Satisfied Employees Through Workplace Spirituality:A Study of the Private Insurance Sector in Punjab.J Bus Ethics. 2013:1-10.

35. Hadzic M. Spirituality and Mental Health: Current Research and Future Directions. J Spirituality Ment Health. 2011;13(4):223-35.

36. Rothman J. Spirituality: What We Can Teach and How We Can Teach It. J Relig Spirituality Soc Work: Soc Thought. 2009; 28(12):161-84.

37. Naimon EC, Mullins ME, Osatuke K. The effects of personality and spirituality on workplace incivility perceptions. J Manage, Spirituality Relig. 2013;10(1):91-110.

38. Petchsawang P, Duchon D. Workplace spirituality, meditation, and work performance. J Manage Spirituality Relig. 2012; 9(2):189-208.

39. Faro AI, Campos CR, Dias ML, Brito SA. Primary health care services: workplace spirituality and organizational performance. $J$ Organiz Change Manage. 2014;27(1):59-82.

40. Park N, Lee BS, Sun F, Klemmack DL, Roff LL, Koenig HG. Typologies of Religiousness/Spirituality: Implications for Health and Well-Being.J Religion Health. 2011;52(3):828-39.

41. Abedijafari H, Rastegar AA. The Emergence of Spirituality in Organizations: Concepts, Definitions, Presumptions and Concep- tual Mode.J Agr Sci Technol. 2007;2(5):99-121.

42. Dvir T, Eden D, Avolio BJ, Shamir B. Impact of Transformational Leadership on Follower Development and Performance: A Field Experiment. Acad Manage J. 2002;45(4):735-44.

43. Najim NA, El Refae GA, Rashed JAA. Exploring the islamic view of spirituality and business. Global Business Econ Review. 2014;16(1):100-9.

44. Graber DR, Johnson JA. Spirituality and healthcare organizations. J Healthc Manag. 2001;46(1):39-50.

45. Tourish D, Pinnington A. Transformational Leadership, Corporate Cultism and the Spirituality Paradigm: An Unholy Trinity in the Workplace? Human Relations. 2002;55(2):147-72.

46. Riaz O. Spirituality and transformational leadership in education. . Florida International University: Ann Arbor; 2012.

47. Franklin S. The influence of spirituality on servant leadership among small business entrepreneurs. . United States Minnesota: Walden University; 2010.

48. Field D. The relationship between transformational leadership and spirituality in business leaders. . United States: Virginia:Regent University; 2004.

49. Hartsfield MK. The internal dynamics of transformational leadership: Effects of spirituality, emotional intelligence, and selfefficacy. . United States: Virginia: Regent University; 2003.

50. Zwart GA. The relationship between spirituality and transformational leadership in public, private, and nonprofit sector organizations. . United States: California: University of La Verne; 2000. 